\title{
Effect of Temperature on the Stability of Plasmid pTG201 and Productivity of $x y l E$ Gene Product in Recombinant Escherichia coli: Development of a Two-stage Chemostat with Free and Immobilized Cells
}

\author{
By SAMI SAYADI, * MONCEF NASRI, FADWA BERRY, \\ JEAN N. BARBOTIN AND DANIEL THOMAS \\ Laboratoire de Technologie Enzymatique, UA no. 523 du CNRS, BP 233, Université de \\ Technologie de Compiègne, 60206 Compiègne Cedex, France
}

(Received 3 December 1986; revised 24 February 1987)

\begin{abstract}
The effect of temperature on the stability of pTG201, a plasmid carrying the $x y l E$ gene (which encodes catechol 2,3-dioxygenase from Pseudomonas putida), and the production of catechol 2,3dioxygenase in free and immobilized Escherichia coli during continuous culture have been studied at various temperatures. Immobilization of cells increased the stability of pTG201 considerably, even under conditions when expression of the $x y l E$ product was enhanced. Since $x y l E$ transcription was controlled by the $\lambda \mathrm{P}_{\mathrm{R}}$ promoter and $c 1857$ repressor, increasing derepression temperatures increased catechol 2,3-dioxygenase productivity and decreased pTG201 stability. A two-stage continuous culture system to overcome the impact of the highlevel expression of the $x y l E$ gene on the stability of pTG201 is described. In the first stage, immobilized cells were grown in the repressed state in order to prevent loss of pTG201, whereas in the second stage, cultures were maintained in the derepressed state.
\end{abstract}

\section{INTRODUCTION}

Bacterial plasmids are widely used as cloning vehicles in recombinant DNA research (Hershfield et al., 1974; Tait et al., 1983). However, many studies have shown that newly constructed recombinant plasmids are not maintained stably when recombinant microorganisms are grown in the absence of antibiotic selection (Noack et al., 1981; Skogman et al., 1983). Commercial production of plasmid-coded gene products in continuous culture is possible only if the recombinant plasmid can be stably maintained in cells (Imanaka \& Aiba, 1981). A variety of experimental approaches to overcome plasmid instability have been proposed (Uhlin et al., 1979; Zurita et al., 1984; Tucker et al., 1984; De Taxis du Poët et al., 1986). The stability of plasmids in host cells may be affected by several factors, such as physiological consequences of expression of genes on the plasmid. Imanaka et al. (1980) and Caulcott et al. (1985) have shown that a high level of foreign gene expression may be detrimental to the carriage of plasmids. The use of temperature-sensitive systems offers the possibility of switching on the synthesis of recombinant proteins at will (Caulcott $\&$ Rhodes, 1986). Plasmids carrying the powerful $\lambda P_{R}$ promoter which is controllable by the product of the temperature-sensitive $\lambda$ repressor gene cI857 have been developed. This repressor, which blocks transcription of the cloned gene, is denatured at temperatures above $37^{\circ} \mathrm{C}$ and causes the overproduction of biomolecules from any gene when regulated by $P_{R}$ following derepression. Siegel \& Ryu (1985) attempted to use a twostage continuous culture process coupled with a temperature-sensitive expression system to obtain high expression from a cloned gene for prolonged periods despite instability caused by the increased expression. Such a system offers the possibility of minimizing the destabilizing effects of high expression, but the levels of production are not reproducible and cannot be maintained for a prolonged period. One cause is the instability of plasmids in the first stage.

Abbreviation: C230, catechol 2,3-dioxygenase. 
As a model system, we have used the recombinant plasmid pTG201, which is a pBR322 derivative carrying the Pseudomonas putida $x y l E$ gene, encoding catechol 2,3-dioxygenase, under the transcriptional control of $\lambda \mathrm{P}_{\mathrm{R}}$ and $c 1857$ repressor. In order to achieve high yields of $x y l E$ gene product together with high stability of pTG201, we have used a two-stage system to separate the phases of growth and product synthesis as suggested by Siegel \& Ryu (1985). Cells were cultivated at $31^{\circ} \mathrm{C}$ in the first chemostat and were continuously transferred to the second stage where the culture temperature $\left(42^{\circ} \mathrm{C}\right)$ denatured the repressor and caused efficient expression. However, to avoid the instability of pTG201, immobilized recombinant cells were used in the first stage. As immobilization considerably increases the stability of recombinant plasmids even under conditions when expression of cloned gene product is enhanced (Nasri et al., 1987), plasmid-carrying cells could be maintained completely stably during continuous culture for a prolonged period in the first stage.

In this paper, we describe the effects of temperature on pTG201 stability and catechol 2,3dioxygenase production in both free and immobilized cells during one-stage and two-stage continuous cultures without selection pressure.

\section{METHODS}

Bacterial strains and plasmid. The bacterial strains used were Escherichia coli W3101 (recA13 trpE Nalr)(Kopecko et al., 1976) and E. coli B. Plasmid pTG201 is a pBR322 derivative carrying the Pseudomonas putida xylE gene, coding for catechol 2,3-dioxygenase, under transcriptional control of the $\lambda \mathrm{P}_{\mathrm{R}}$ promoter and $c 1857$ repressor. Plasmid pTG201, a generous gift from Transgene SA, France, was constructed by D. F. Gaffney (personal communication).

Media. The medium used throughout the experiments was L broth (LB: $1 \%$, w/v, tryptone, $0.5 \%$ yeast extract, $0.5 \% \mathrm{NaCl})$. For immobilized cells, $\mathrm{LB}$ medium was supplemented with $0.1 \mathrm{M}-\mathrm{KCl}$. Agar $(1.5 \% \mathrm{w} / \mathrm{v})$ was added to LB medium to prepare LB agar plates.

Immobilization procedure. Immobilized growing cells were prepared using the carrageenan method (Takata et al., 1977). A $0.5 \mathrm{ml}$ volume from a preculture was added to $9.5 \mathrm{ml} 2.1 \%$ (w/v) K-carrageenan E407 (a generous gift from CECA France) and suspended by stirring at $42^{\circ} \mathrm{C}$. This mixture was pumped at a rate of approximately $2 \mathrm{ml} \mathrm{min}{ }^{-1}$ into $40 \mathrm{ml} \mathrm{LB}$ medium containing $0.3 \mathrm{M}-\mathrm{KCl}$, to form beads with a diameter of about $3 \mathrm{~mm}$.

Cultivation conditions. Continuous cultures were carried out in $50 \mathrm{ml}$ volumes in $100 \mathrm{ml}$ glass vessels maintained at a fixed temperature, with an aeration rate of $170 \mathrm{ml} \mathrm{min}^{-1}$. For free cultures, experiments were generally started with an overnight batch culture in $20 \mathrm{ml} \mathrm{LB}$ medium containing $50 \mu \mathrm{g}$ ampicillin $\mathrm{ml}^{-1}$. The chemostat was then inoculated with $0.4 \mathrm{ml}$ of this culture. After batch growth for 4-5 h, fresh medium flow was started at the desired dilution rate.

For immobilized cultures, about $10 \mathrm{ml}$ gel beads was transferred to the chemostat, and incubated with $40 \mathrm{ml}$ growth medium supplemented with $0.1 \mathrm{M}-\mathrm{KCl}$. Continuous flow of LB medium was initiated immediately.

For two-stage continuous culture, immobilized recombinant $E$. coli cells were produced in the first stage. Cells released from gel beads were continuously transferred to the second stage. The first chemostat was inoculated as for the single continuous immobilized system. The second stage was initially filled with $50 \mathrm{ml}$ fresh LB medium. The temperatures of the first and the second stage were maintained at $31^{\circ} \mathrm{C}$ and $42{ }^{\circ} \mathrm{C}$, respectively.

Plasmid stability test. To determine the proportion of cells in the culture containing the plasmid, samples were withdrawn from the continuous cultures and spread on to LB agar plates. After overnight incubation at $37^{\circ} \mathrm{C}$, the proportion of cells containing pTG201 $\left(x y l E^{+}, \mathrm{Ap}^{\mathrm{T}}\right)$ was calculated after spraying the colonies with an aqueous solution of $0.5 \mathrm{M}$-catechol. A yellow colour indicates a catechol 2,3-dioxygenase-producing colony (Zukowsky $e t$ al., 1983).

Solubilization of gel beads. Gel beads were removed from the fermenter at regular intervals and then washed twice in $0.8 \% \mathrm{NaCl}$ and dissolved in $1 \%$ sodium citrate.

Assay for activity of catechol 2,3-dioxygenase $(C 23 O ; E C 1.13 .11$.2). The conversion by $\mathrm{C} 23 \mathrm{O}$ of catechol to 2hydroxymuconic semialdehyde was determined spectrophotometrically as described by Sala-Trepat \& Evans (1971).

DNA isolation. Whole-cell lysates were prepared by the method of Eckhardt (1978), as modified by Projan et al. (1983).

Gel electrophoresis and determination of plasmid copy number. Electrophoresis of whole cell lysates was done on horizontal $1 \%(w / v)$ agarose slab gels. DNA bands were visualized under UV light after staining with ethidium bromide. The DNA content of bands was determined by microdensitometer tracing of photographic negatives.

The number of pTG201 copies per cell was calculated by using the following equation (Projan et al., 1983): $C_{\mathrm{p}}=$ $D_{\mathrm{p}} M_{\mathrm{c}} / D_{\mathrm{c}} M_{\mathrm{p}}$, where $C_{\mathrm{p}}$ indicates plasmid copies per cell, $D_{\mathrm{p}}$ and $D_{\mathrm{c}}$ are the amounts of plasmid and chromosomal DNA in the gel, $M_{\mathrm{p}}$ is the molecular mass of plasmid, and $M_{\mathrm{c}}$ that of the total chromosomal DNA per cell. 


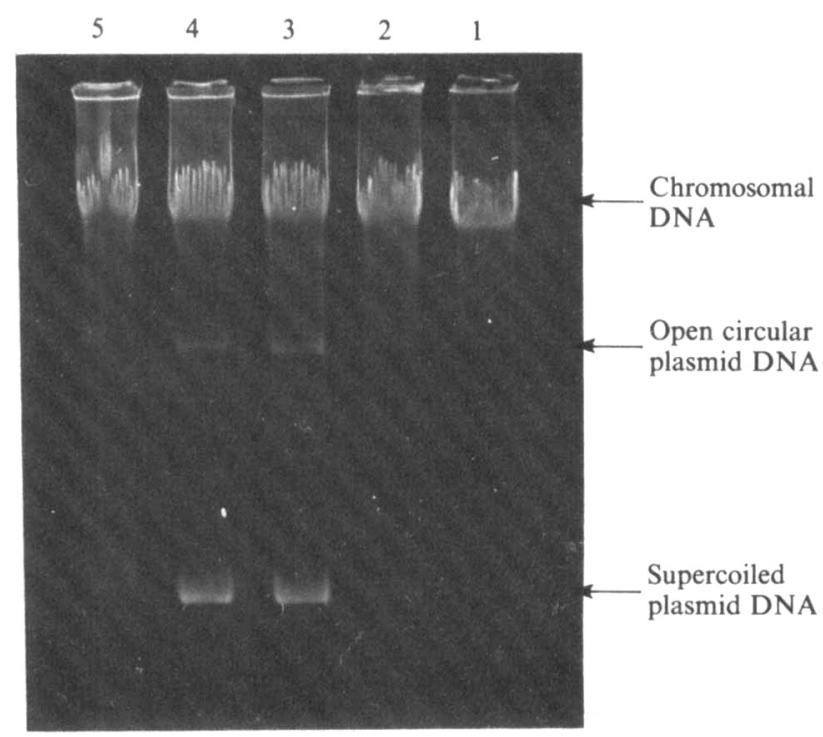

Fig. 1. Plasmid copy number of $E$. coli W3101(pTG201) at various stages of growth: (1) early exponential, (2) mid-exponential, (3) late-exponential, (4) stationary, (5) decline.

\section{RESULTS AND DISCUSSION}

The stability of pTG201 and C23O productivity were tested in both $E$. coli B and $E$. coli W3101 cells in continuous cultures. The copy number of pTG201 per cell was 40-50 in $E$. coli B and 70-80 E. coli $\mathrm{W} 3101$. The copy number of pTG201 in both strains was determined at different stages of bacterial growth; it was maximal during the stationary phase (Fig. 1). Several reports have shown that the plasmid copy number may influence the stability of plasmids (Jones et al., 1980). Therefore, to start from a culture containing the maximum copy number of pTG201, precultures were allowed to grow for at least $12 \mathrm{~h}$.

\section{Effects of temperature on the stability of pTG201 and C23O production in free cells}

The dilution rate in these experiments was about $0.9 \mathrm{~h}^{-1}$.

Fig. 2(a) shows that the stability of pTG201 in $E$. coli B was strongly affected by the culture temperature. The initial percentage of cells carrying pTG201 at 31,37 and $42{ }^{\circ} \mathrm{C}$ was 97,85 , and $94 \%$, respectively. At $31^{\circ} \mathrm{C}$, the plasmid was moderately stable : after 83 generations more than $82 \%$ of the cells were $x y l E^{+}$. However, at higher temperatures the plasmid was extremely unstable, since at 37 and $42{ }^{\circ} \mathrm{C}$ only 40 and $35 \%$ of the cells still expressed C23O activity after about 87 and 67 generations, respectively. The rate of appearance of pTG201-free cells, and the concentrations of viable cells in the effluent at steady-state, are shown in Tables 1 and 2, respectively.

Similar experiments to examine the effect of temperature on the stability of pTG201 were done with E. coli W3101. At $31^{\circ} \mathrm{C}$, pTG201 was extremely stable (no pTG201-free cells were found after 280 generations). In contrast, after about 250 generations at 37 and $42{ }^{\circ} \mathrm{C}, 12$ and $48 \%$ of cells, respectively, had lost pTG201 (data not shown).

The effect of culture temperature on $\mathrm{C} 230$ production by $E$. coli $\mathrm{B}$ was also investigated (Fig. $2 b$ ). $\mathrm{C} 23 \mathrm{O}$ formation does occur at $31{ }^{\circ} \mathrm{C}$, even though the promoter $\mathrm{P}_{\mathrm{R}}$ is maintained in a repressed state by the $c I$ gene product at this temperature. At higher temperatures, a more than fivefold increase in $\mathrm{C} 23 \mathrm{O}$ activity was obtained : the activity increased significantly for the first 25 generations and then decreased (Fig. $2 b$ ). This decrease in $\mathrm{C} 23 \mathrm{O}$ activity was correlated with the decrease in the proportion of cells containing pTG201.

Two explanations for the loss of pTG201 from $E$. coli B cells may be considered: (1) because of the absence of a partition mechanism in pTG201, which is necessary for stable inheritance of the plasmid in a population of dividing cells (Meacock \& Cohen, 1980; Nordström et al., 1980), 


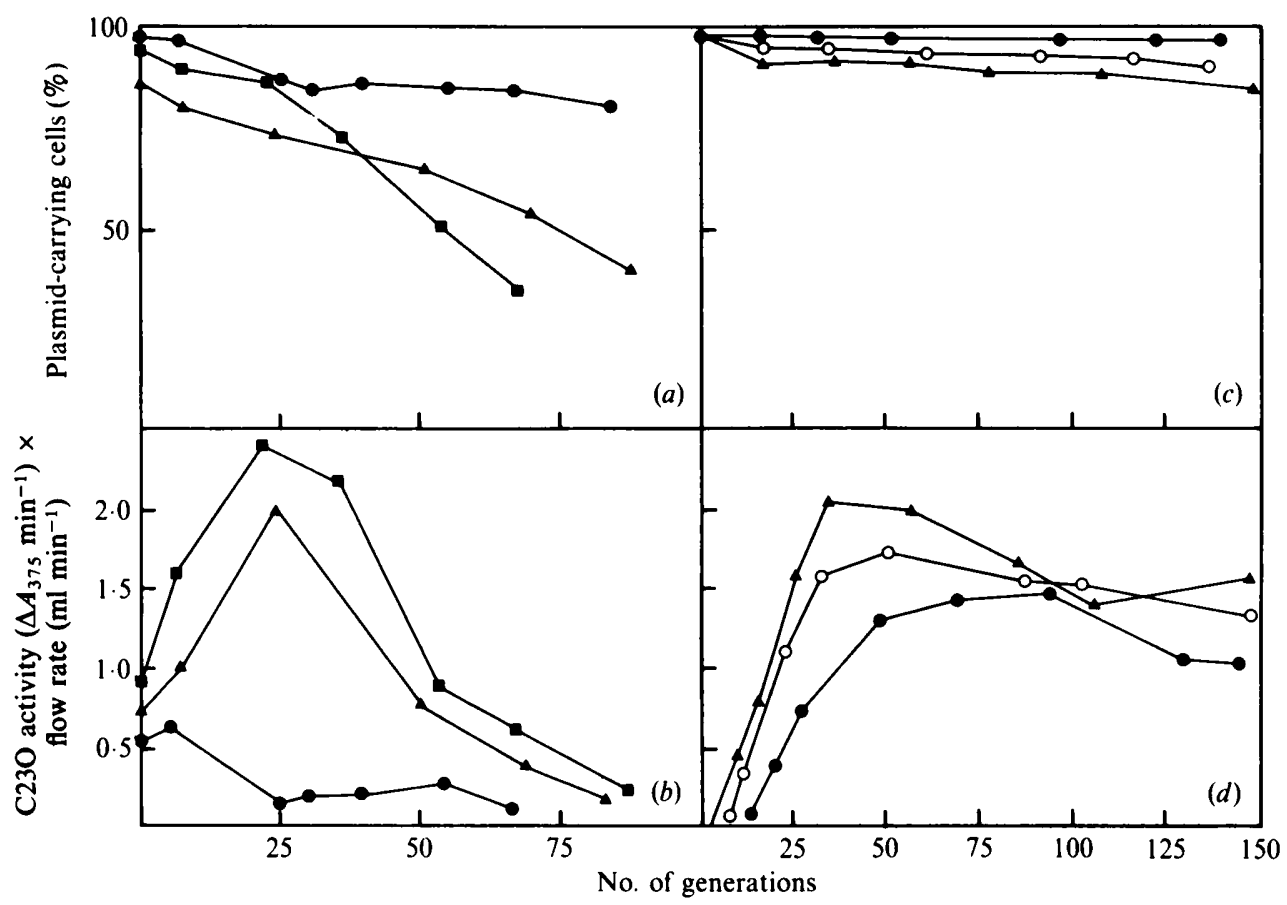

Fig. 2. Effect of temperature on the stability of plasmid pTG201 $(a, c)$ and C23O productivity $(b, d)$ in continuous cultures of free $(a, b)$ and immobilized $(c, d) E$. coli $\mathrm{B}(\mathrm{pTG} 201)$., $31^{\circ} \mathrm{C} ; \mathrm{O}, 34^{\circ} \mathrm{C} ; \Delta$, $37^{\circ} \mathrm{C} ; \mathbf{\square}, 42^{\circ} \mathrm{C}$.

plasmid-free cells may be generated from plasmid-containing cells; (2) differences in growth rate between plasmid-free and plasmid-containing cells. The results in Table 3 indicate that the growth rates of pTG201-containing $E$. coli B are lower than those of pTG201-free cells. Therefore, when pTG201-free cells appear in the culture (due to the spontaneous plasmid loss through segregation during cell division), they will compete with pTG201-containing cells, and after prolonged incubation, overgrow the culture. The differences in growth rate between pTG201-free and pTG201-containing cells increase with increasing temperature (Table 3).

\section{Effects of temperature on pTG201 stability and C23O production in immobilized cells}

For this study, continuous fermentations were conducted only at 31,34 and $37^{\circ} \mathrm{C}$, because the gel beads are dissolved at higher temperatures. The dilution rate of the immobilized cell cultures was $3 \cdot 2 \mathrm{~h}^{-1}$. Due to the high dilution rate, the cells which are continuously released from the gel beads cannot divide in the chemostat. Consequently, information concerning the evolution of the system as a function of time can be obtained from the released cells.

Fig. 2(c) shows the very high stability of pTG201 in immobilized $E$. coli B cells when compared to that with free cells. At $31{ }^{\circ} \mathrm{C}$ the initial percentage of plasmid-bearing cells was $98 \%$ and remained nearly the same after about 140 generations. Plasmid stability decreased relatively at higher temperatures, but was still high even at derepression temperatures of 34 and $37^{\circ} \mathrm{C}$ (Fig. 2c). Immediately after initiation of a chemostat population and for the first 15 generations, the frequency of plasmid-containing cells decreased and then remained nearly constant. The percentages of plasmid-bearing cells after 140 generations at 34 and $37^{\circ} \mathrm{C}$ were 91 and $88 \%$, respectively (initial percentage $98 \%$ ). This increased pTG201 stability in immobilized cells may have resulted from absence of competition between plasmid-free and plasmidcontaining cells within the gel beads and/or to the mechanical properties of the gel bead system, which may only allow a limited number of cell divisions to occur in each clone of cells before the clone escapes from the gel bead. Such escaped populations are washed out by flow before much 
Table 1. Rate of loss of pTG201 in E. coli B per cell generation

The results are ranges, taken from three independent experiments.

$\begin{array}{ccc}\begin{array}{c}\text { Temp. } \\ \left({ }^{\circ} \mathrm{C}\right)\end{array} & \overbrace{\text { Free cells }}^{\text {Rate of loss of pTG201 }(\%)} & \text { Immobilized cells* } \\ 31 & 0 \cdot 18-0.22 & 0 \\ 34 & \text { ND } & 0.16-0.20 \\ 37 & 0.34-0.57 & 0.38-0.57 \\ 42 & 1.25-1.35 & \dagger\end{array}$

ND, Not determined.

* Rate of loss of pTG201 from cells grown in gel beads for the first 16 generations.

† Gel beads are dissolved at $42{ }^{\circ} \mathrm{C}$.

Table 2. Numbers of viable E. coli $B$ cells

Viable cell number of immobilized cells is expressed per $\mathrm{ml}$ of gel, and that of free and released cells per ml of liquid medium. The results are means of three independent experiments. The standard errors were within $3 \%$ of the mean.

$\begin{array}{cccc}\begin{array}{c}\text { Temp. } \\ \left({ }^{\circ} \mathrm{C}\right)\end{array} & \text { Free cells } & \text { Released cells } & \text { Immobilized cells } \\ 31 & 1.6 \times 10^{9} & 1.8 \times 10^{8} & 1.5 \times 10^{10} \\ 34 & \text { ND } & 1.8 \times 10^{8} & 1.5 \times 10^{10} \\ 37 & 3.0 \times 10^{9} & 1.8 \times 10^{8} & 1.4 \times 10^{10} \\ 42 & 1.9 \times 10^{9} & \dagger & \dagger \\ & \text { ND, Not determined. } \\ & + \text { Gel beads are dissolved at } 42^{\circ} \mathrm{C} .\end{array}$

Table 3. Effect of temperature on growth rate of plasmid-free and plasmid-containing $E$. coli $B$

The results are means of three independent experiments. The standard errors were within $3 \%$ of the mean.

\begin{tabular}{|c|c|c|c|}
\hline \multirow[b]{2}{*}{$\begin{array}{l}\text { Temp. } \\
\left({ }^{\circ} \mathrm{C}\right)\end{array}$} & \multicolumn{2}{|c|}{ Growth rate $\left(h^{-1}\right)$} & \\
\hline & $\begin{array}{l}\text { pTG201-free } \\
\text { (a) }\end{array}$ & $\begin{array}{l}\text { pTG201-containing } \\
\text { (b) }\end{array}$ & $\begin{array}{c}\text { Ratio } \\
a / b\end{array}$ \\
\hline 31 & $1 \cdot 37$ & $1 \cdot 36$ & 1.01 \\
\hline 37 & $2 \cdot 61$ & $2 \cdot 45$ & 1.07 \\
\hline 42 & 1.66 & 1.48 & $1 \cdot 12$ \\
\hline
\end{tabular}

cell division can occur, ensuring that any cured cells that arise are unable to take over the culture. The lost clones are continuously being replenished by new ones which reside deeper in the gel bead and whose growth was initially retarded by nutrient or oxygen deprivation. These are made accessible at the bead surface due to the sloughing of the outer matrix as it is disrupted by the escaping clones (De Taxis du Poët et al., 1986; Nasri et al., 1987).

The rate of loss of pTG201 from free $E$. coli B cells at $37^{\circ} \mathrm{C}$ was similar to that of immobilized cells (Table 1) at the same temperature for the first 20 generations. These results indicate that cells immobilized in gel beads exhibit the same behaviour as free cells during growth in continuous culture. At higher temperatures $\left(37^{\circ} \mathrm{C}\right)$, the cells grew rapidly in the gel beads, while at lower temperatures $\left(31^{\circ} \mathrm{C}\right)$, growth was slower, until a steady state was reached. The maximum number of living cells in gel beads was similar at the three temperatures used (Table 2). The concentration of viable released cells in the effluent at steady-state was also similar at each temperature. 


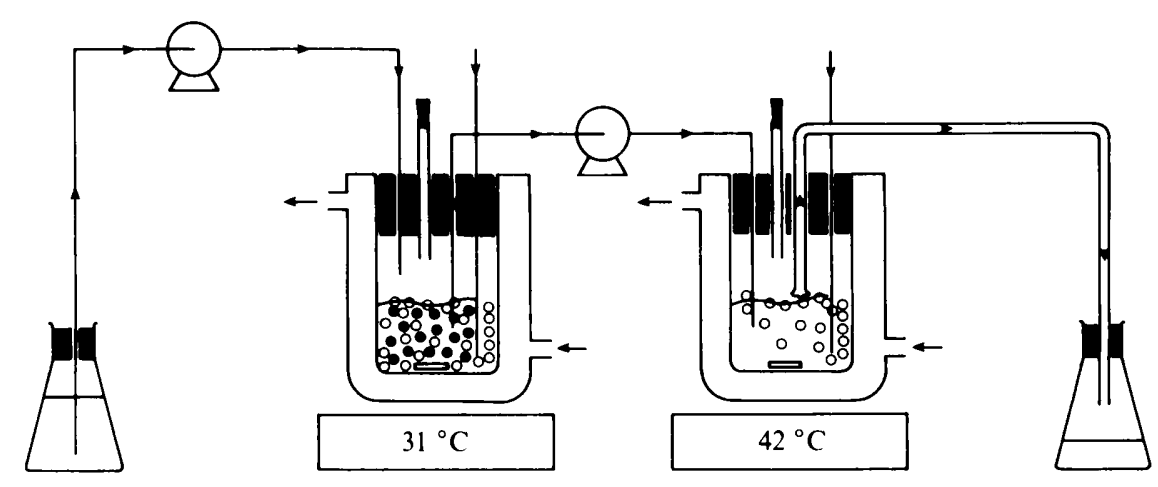

Fig. 3. Schematic representation of the configuration of the two-stage continuous culture.

The production of $\mathrm{C} 23 \mathrm{O}$ at different temperatures, as a function of generations of cells released from gel beads, is shown in Fig. 2(d). C23O production increased with increasing temperature, but not as markedly as observed in the free continuous system.

No loss of pTG201 was detected in E. coli W3101 after 250 generations, even at 31 and $34{ }^{\circ} \mathrm{C}$. Since pTG201 was more stable in $E$. coli W3101 than in $E$. coli B under both free and immobilized continuous culture conditions, the former strain was used for all subsequent work.

\section{Two-stage continuous cultures}

The instability of pTG201 appeared to be associated with expression of the $x y l E$ gene. In order to minimize the deleterious effects of high levels of expression of cloned gene product, we separated the phases of growth and expression of $x y l E$ gene. In the first stage, recombinant cells were grown in the repressed state, and then continuously transferred to the second stage where derepression was induced (Fig. 3).

The above results, and previous work in our laboratory (De Taxis du Poët et al., 1986; Nasri et al., 1987), show that immobilization of cells offers certain advantages: (a) higher stability of pTG201; (b) higher productivities due to high cell concentrations obtained in the gel bead and the higher productivity of released cells from the gel beads when compared to that obtained with free-cell culture. The increase in the cell concentration through immobilization may lead to an increase in the overall production of cloned gene products. We therefore developed an immobilized system to produce released cells, in the repressed state, in the first stage. After immobilization, the gel beads were transferred to the chemostat and the continuous flow of LB medium was immediately initiated. The dilution rate in both stages was about $3.45 \mathrm{~h}^{-1}$, and the temperatures in the first and second stages were 31 and $42^{\circ} \mathrm{C}$, respectively. Samples were withdrawn from both stages and assayed for pTG201 stability and C23O activity (Fig. 4). After 230 generations, $3 \%$ of the cells had lost the plasmid in the derepressed culture, whereas in the repressed culture, no loss of pTG201 was observed after a similar number of generations (Fig. $4 a$ ). This difference was due to segregation of plasmid-free cells in the second stage. We found no pTG201-free segregants even after 400 generations in the first stage. Production of $\mathrm{C} 23 \mathrm{O}$ of both uninduced and induced cultures increased significantly and then declined during the first 50 generations (Fig. $4 b$ ). No change in $\mathrm{C} 23 \mathrm{O}$ activity was observed during extended experiments (100-230 generations). The $\mathrm{C} 23 \mathrm{O}$ activity of released cells in the second stage was five times higher than that in the first stage (Fig. $4 b$ ). Furthermore, derepression by temperature-shift was not accompanied by a decrease in the number of living cells (data not shown).

In conclusion, such a two-stage process coupled with a temperature-sensitive expression system offers the following advantages: (1) high stability of the recombinant plasmid in the first stage, since in contrast to a free system, the immobilized system shows total stability of pTG201 


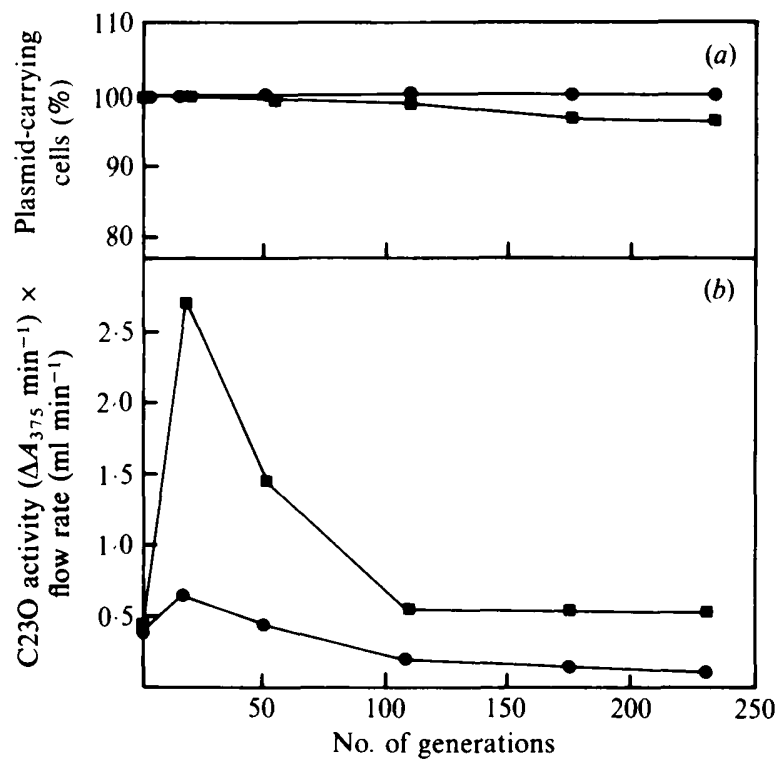

Fig. 4. Stability of pTG201 (a) and C230 productivity $(b)$ in a two-stage continuous culture of $E$. coli W3101(pTG201). First stage; $\square$, second stage.

in continuous culture, without selective pressure, for an extended number of generations; (2) high cell concentration in the first stage. Previous reports (Shinmyo et al., 1982; Wada et al., 1980; Wang \& Wang, 1983) have shown that through immobilization, a significantly higher cell concentration can be obtained when compared to free-cell fermentations. These two factors therefore lead to an increase in the overall productivity of cloned gene products in the second stage.

\section{REFERENCES}

Caulcott, C. A. \& RHodes, M. (1986). Temperatureinduced synthesis of recombinant proteins. Trends in Biotechnology 4, 142-146.

Caulcott, C. A., Lilley, G., Wright, E. M., Robinson, M. K. \& Yarranton, G. T. (1985). Investigation of the instability of plasmids directing the expression of Met-prochymosin in Escherichia coli. Journal of General Microbiology 131, 33553365.

De Taxis du Poët, P., Dhulster, P., Barbotin, J. N. \& Thomas, D. (1986). Plasmid inheritability and biomass production: comparison between free and immobilized cell cultures of Escherichia coli BZ18 without selection pressure. Journal of Bacteriology 165, 871-877.

ECKHARDT, T. (1978). A rapid method for identification of plasmid desoxyribonucleic acid in bacteria. Plasmid 1, 548-588.

HeRshField, V., BOYeR, H. W., LOVETT, M., YANofSKY, C. \& HeLinSKI, D. (1974). Plasmid ColEl as a molecular vehicle for cloning and amplification of DNA. Proceedings of the National Academy of Sciences of the United States of America 71, 34553461.

ImaNAKA, T. \& Aiba, S. (1981). A perspective on the application of genetic engineering: stability of recombinant plasmid. Annals of the New York Academy of Sciences 369, 1-14.

Imanaka, T., Tsunekawa, H. \& Aiba, S. (1980). Phenotypic stability of trp recombinant plasmids in Escherichia coli. Journal of General Microbiology 118, 253-261.

Jones, I. M., Primrose, S. B., Robinson, A. \& Ellwood, D. C. (1980). Maintenance of some ColE1-type plasmids in chemostat culture. Molecular and General Genetics 180, 579-584.

Kopecko, D. J., Brevet, J. \& Cohen, S. N. (1976). Involvement of multiple translocating DNA segments and recombinational hotspots in the structural evolution of bacterial plasmids. Journal of Molecular Biology 108, 333-360.

Meacock, P. A. \& Cohen, S. N. (1980). Partitioning of bacterial plasmids during cell division. A cis-acting locus that accomplishes stable plasmid inheritance. Cell 20, 529-542.

Nasri, M., Sayadi, S., Barbotin, J. N., Dhulster, P. \& THOMAS, D. (1987). The influence of immobilization on the stability of pTG201 recombinant plasmid in some strains of Escherichia coli. Applied and Environmental Microbiology 53, 740-744.

Noack, D., Roth, K., Geuther, R., Muller, G., UNdisz, K., Hoffmeier, C. \& Gaspar, S. (1981). 
Maintenance and genetic stability of vector plasmids pBR322 and pBR325 in Escherichia coli K-12 strains grown in a chemostat. Molecular and General Genetics 188, 338-344.

Nordström, K., Molin, S. \& Aagard-Hansen, H. (1980). Partitioning of plasmid R1 in Escherichia coli. I. Kinetics of loss of plasmid derivatives deleted of the par region. Plasmid 4, 215-227.

Projan, S. J., Carleton, S. \& Novick, R. P. (1983). Determination of plasmid copy number by fluorescence densitometry. Plasmid 9, 182-190.

Sala-Trepat, J. M. \& Evans, W. C. (1971). The meta cleavage of catechol by Agrobacter species 4oxalocrotonate pathway. European Journal of Biochemistry 20, 400-413.

Shinmyo, A., Kimura, H. \& OKadA, H. (1982). Physiology of $\alpha$-amylase production by immobilized Bacillus amyloliquefaciens. European Journal of Applied Microbiology and Biotechnology 14, 7-12.

SIEGEL, R. \& RYU, D. D. Y. (1985). Kinetic study of instability of recombinant plasmid pPLc23trpA1 in Escherichia coli using two-stage continuous culture system. Biotechnology and Bioengineering 27, 28-33.

Skogman, G., Nilsson, J. \& Gustafson, P. (1983). The use of a partition locus to increase stability of tryptophan-operon-bearing plasmids in Escherichia coli. Gene 23, 105-115.

Tait, R. C., Close, T. J., Lundeuist, R. C., Hagiya, M., Rodriguez, R. L. \& Kato, C. I. (1983). Construction and characterization of a versatile broad host range DNA cloning system for Gram negative bacteria. Bio/Technology 1, 269-275.
Takata, I., Tosa, T. \& Chibata, I. (1977). Screening of matrix suitable for immobilization of microbial cells. Journal of Solid Phase Biochemistry 2, 225-236.

TuCKer, W. T., Miller, C. A. \& Cohen, S. N. (1984). Structural and functional analyses of the par region of the pSC101 plasmid. Cell 38, 191-201.

Uhlin, B. E., Molin, S., Gustafsson, P. \& NordSTRÖM, K. (1979). Plasmids with temperaturedependent copy number for amplification of cloned genes and their products. Gene 6, 91-106.

Wada, M., Kato, J. \& Chibata, I. (1980). Continuous production of ethanol using immobilized growing yeast cells. European Journal of Applied Microbiology and Biotechnology 10, 275-287.

Wang, G. \& Wang, D. I. C. (1983). Production of acetic acid by immobilized whole cells of Clostridium thermoaceticum. Applied Biochemistry and Biotechnology 8, 491-503.

Zukowsky, M. N., Gaffney, D. F., SPECK, D., Kauffman, M., Findelli, A., Wisecup, A. \& LECOQ, J. P. (1983). Chromogenic identification of genetic regulatory signals in Bacillus subtilis based on expression of a cloned Pseudomonas gene. Proceedings of the National Academy of Sciences of the United States of America 80, 1101-1105.

Zurita, M., Bolivar, F. \& Soberon, X. (1984). Construction and characterisation of new cloning vehicles. VII. Construction of plasmid pBR327par, a completely sequenced, stable derivative of pBR327 containing the par locus of pSC101. Gene 28, 119122. 